\title{
A thiirane linker for the isopeptide mimetics by the peptide ligation
}

\author{
Toru Kawakami $^{\mathrm{a}, *}$, Yuichi Mishima ${ }^{\mathrm{a}}$, Misaki Kinoshita ${ }^{\mathrm{a}}$, Young-Ho Lee ${ }^{\mathrm{a}}$, and Isao Suetake ${ }^{\mathrm{a}, \mathrm{b}}$ \\ ${ }^{a}$ Institute for Protein Research, Osaka University, 3-2 Yamadaoka, Suita, Osaka 565-0871, Japan \\ ${ }^{b}$ CREST, Japan Science and Technology Agency, 4-1-8 Honcho, Kawaguchi, Saitama 332-0012, Japan
}

\section{ARTICLE INFO}

\section{ABSTRACT}

\section{Article history:}

Received

Received in revised form

Accepted

Available online

\section{Keywords:}

CPE ligation

histone

post-translational modification

thiirane

ubiquitin
2-Aminomethylthiirane was used to attach a 1,2-amino-thiol moiety at thiol groups of peptides for use in peptide ligation to produce isopeptide mimetics. To confirm the strategy, a ubiquitinated histone $\mathrm{H} 3$ peptide was prepared, and the ubiquitin was correctly folded judging from $\mathrm{CD}$ spectra with no influence by the random $\mathrm{H} 3$ peptide.

2009 Elsevier Ltd. All rights reserved.

* Corresponding author. Tel.: +81-6-6879-8602; fax: +81-6-6879-8603; e-mail: kawa@ protein.osaka-u.ac.jp 
The site-selective modification of proteins such as posttranslational modification (PTM) and fluorescence labeling makes up important methods for studies of protein functions. ${ }^{1,2}$ Histone proteins form an octamer as a core of the nucleosome, which is a basic unit of chromatin and which consists of two copies each of four different core histones, H2A, H2B, H3, and H4 with DNA. The PTMs of histones, such as acetylation, methylation, phosphorylation, and so on, are crucial, in that they determine how the molecule will participate in the epigenetic regulation of gene expression. ${ }^{3-8}$ We previously reported on the preparation of histone $\mathrm{H} 3$ containing an $\varepsilon$-trimethylated Lys residue. 9,10

Ubiquitination is an important PTM, in which the C-terminus of ubiquitin (Ub), a 76 amino acid residue peptide, is attached to the side-chain amino group of Lys residues by an isopeptide bond. $^{11,12}$ Histones are also ubiquitinated to regulate their functions. ${ }^{3,4,13,14}$ Recently the ubiquitinated histones H2A and $\mathrm{H} 2 \mathrm{~B}$ were prepared based on elegant chemistry that involved the construction of native isopeptide structures. ${ }^{15-17}$ The overall synthetic strategies are a bit complex and require considerable skill. On the other hand, ubiquitin can be installed at a Cys residue through, for example, via a disulfide or a thioether. ${ }^{11,18,19}$ These approaches are useful because the reactions are more straightforward. Here we report on an alternative method for preparing an isopeptide-mimetic structure, in which thiiran-2ylmethanamine (2-aminomethylthiirane 2 ) is used as a linker for peptide ligation (Scheme 1). 2-Aminomethylthiirane $\mathbf{2}$ is reacted with a Cys-containing peptide $\mathbf{1}$ to give the 1,2 -amino-thiol $\mathbf{3}^{20-22}$ and the peptide thioester $4^{23-25}$ is then reacted by native chemical ligation $^{26-28}$ to produce the isopeptide-mimetic molecule 5. In this report, the ubiquitinated histone $\mathrm{H} 3$ peptide was prepared as a model molecule. Histone $\mathrm{H} 3$ was reported to be ubiquitinated at Lys 18 or 23 to regulate maintenance DNA methylation by DNA methyltransferases. ${ }^{13,14}$

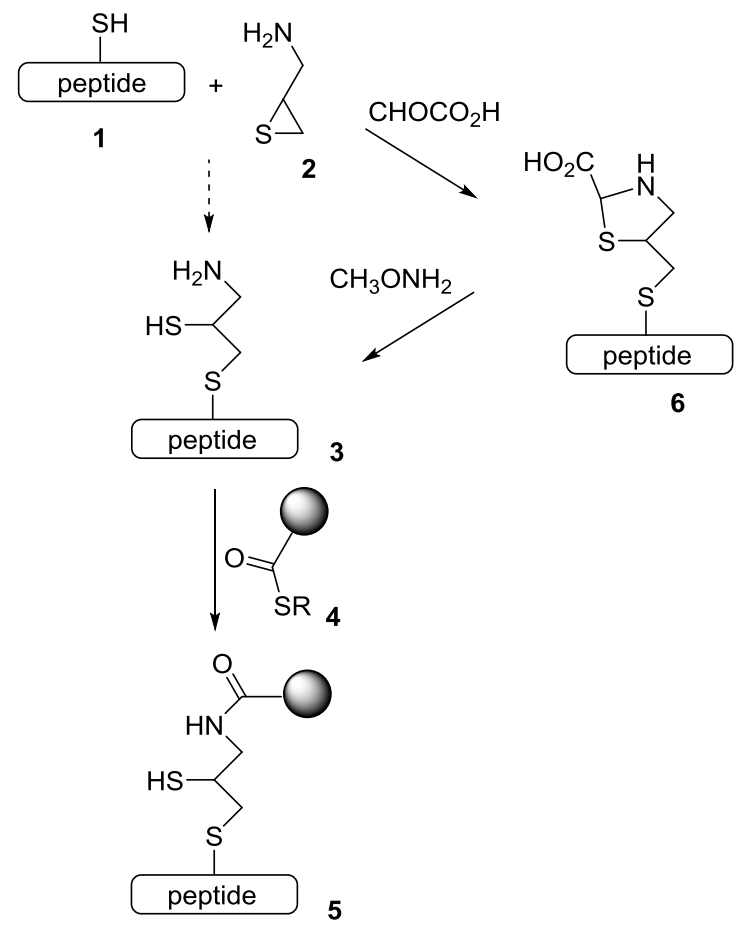

Scheme 1. Formation of an isopeptide-mimetic linkage using a 2aminomethylthiirane linker 2.

When a model peptide, Ala-Lys-Gly-Thr-Arg-Ala-Val-ThrCys-Tyr-Thr-Ser-NH $\mathrm{NH}_{2}$ (1a), was reacted with an excess amount of 2-aminomethylthiirane 2 in sodium phosphate buffer ( $\mathrm{pH} 8.1$ ), oligomers of $\mathbf{2}$, as a result of the subsequent reaction of the 1,2amino-thiol peptide 3a with $\mathbf{2}$, were observed, while peptide 1a remained (Figure S3 in supplemental data). Thiiranes are known to readily undergo oligomerization. ${ }^{22}$ Therefore, we attempted to terminate the 1,2-amino-thiol moiety as the thiazolidine 6 by reaction with aldehydes (Scheme 1). Although formaldehyde was not effective, the thiazolidine $\mathbf{6 a}$, which contains two chiral carbons, was produced in the presence of glyoxylic acid, and the subsequent addition of $O$-methylhydroxylamine to the reaction mixture directly produced the desired 1,2-amino-thiol $\mathbf{3 a}$ in a yield of $68 \%$ from peptide 1a with negligible amounts of the dimeric product 3a' (Figure 1 (A),(B)). Regiochemistry of the ring opening site of the thiirane was determined by the NMR of a product, obtained by the reaction of $\mathrm{N}$-tert-buthoxycarbonyl-2aminomethylthiirane and ethyl 3-mercaptopropionate, and amino acid analysis of 3a showed that the Cys residue was modified (peptides are listed in the supplemental data).

The ligation of peptide $\mathbf{3 a}$ at the side chain 1,2-amino-thiol moiety with the model peptide, Fmoc-Arg-Gly-Asn-Tyr-AspAla-Cys-Pro-OCH${ }_{2} \mathrm{CO}-\mathrm{Tle}-\mathrm{NH}_{2}$ (4a) (Tle: tert-leucine), in which the sequence, -Cys-Pro- $\mathrm{OCH}_{2} \mathrm{CO}-(\mathrm{CPE})$, at the $\mathrm{C}$ terminus constitutes a thioester-forming structure, ${ }^{29-33}$ in phosphate buffer ( $\mathrm{pH}$ 7.9) in the presence of 2,2,2trifluoroethanethiol (TFET) ${ }^{34}$ produced the isopeptide-mimetic peptide 5a in a yield of 79\% (Figure 1 (C)). Attempts to remove the thiol group under desulfurization conditions ${ }^{35}$ resulted in the cleavage at the isopeptide-mimetic moiety to produce the following peptides: Ala-Lys-Gly-Thr-Arg-Ala-Val-Thr-Ala-TyrThr-Ser- $\mathrm{NH}_{2}$ (1a') and the Fmoc-Arg-Gly-Asn-Tyr-Asp-Ala$\mathrm{NH}_{2}$ derivative 4a', a mass analysis of which indicated a $\mathrm{C}$ terminal allyl amide (supplemental data), which might be due to radical $\beta$-fragmentation. ${ }^{36}$ Although it was not possible to remove the thiol group of the isopeptide-mimetic structure, the thiol functionality can be used for further labeling such as fluorescent probes.

The histone $\mathrm{H} 3$ peptide, with $\mathrm{Ub}$ attached at the 23 position ${ }^{13}$ through the isopeptide-mimetic structure, $\left[\mathrm{Cys}\left(\mathrm{CH}_{2} \mathrm{CH}(\mathrm{SH}) \mathrm{CH}_{2} \mathrm{NHCO}-\mathrm{Ub}\right)^{23}\right] \mathrm{H} 3(1-35)-\mathrm{NH}_{2} \quad$ (5b), was next synthesized. The amino acid sequences are shown in Figure 2. Histone H3 contains 135 amino acid residues, and its $\mathrm{N}$ terminal region is known to be flexible and to accept various types of PTM. $^{5}$ The 1,2-amino-thiol peptide, $\left[\mathrm{Cys}\left(\mathrm{CH}_{2} \mathrm{CH}(\mathrm{SH}) \mathrm{CH}_{2} \mathrm{NH}_{2}\right)^{23}\right] \mathrm{H} 3(1-35)-\mathrm{NH}_{2} \quad(\mathbf{3 b})$ was synthesized by the reaction of $\left[\mathrm{Cys}^{23}\right] \mathrm{H} 3(1-35)-\mathrm{NH}_{2}$ (1) and thiirane 2 via the thiazolidine $\mathbf{6 b}$ by a one-pot procedure in a yield of $47 \%$ after RP-HPLC purification (Figure 3 (A),(B)). Only a small amount of the oligomer $\mathbf{3 b}$ 'of $\mathbf{2}$, attached to the $\mathrm{H} 3$ peptide, was observed. The Ub-CPE, Ub-Cys-Pro-OCH${ }_{2} \mathrm{CO}-\mathrm{Tle}-$ $\mathrm{NH}_{2}$ (4b), which was prepared by Fmoc solid phase peptide synthesis (SPPS), ${ }^{37}$ was then ligated with the 1,2-amino-thiol peptide $\mathbf{3 b}$ in the presence of 4-mercaptophenylacetic acid (MPAA) as a catalyst ${ }^{38}$ to give the H3-Ub isopeptide-mimetic peptide $\mathbf{5 b}$ in a yield of $56 \%$ after RP-HPLC purification (Figure $3(\mathrm{C}))$. 
(A)

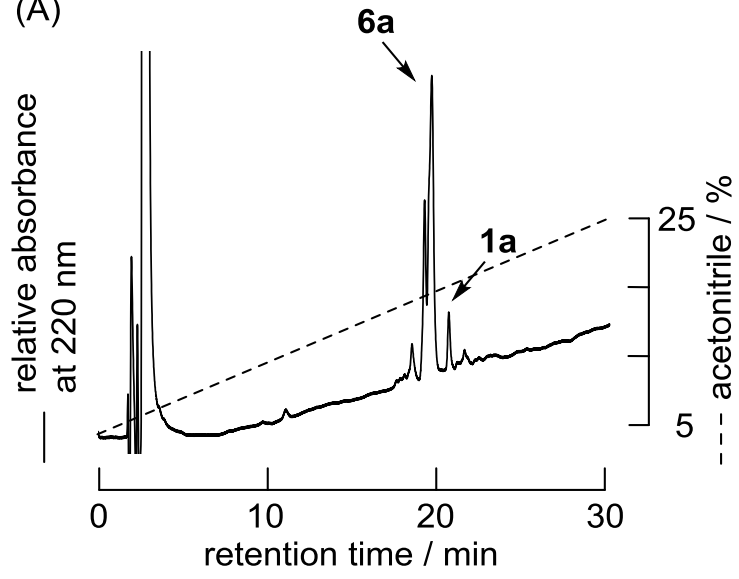

(B)
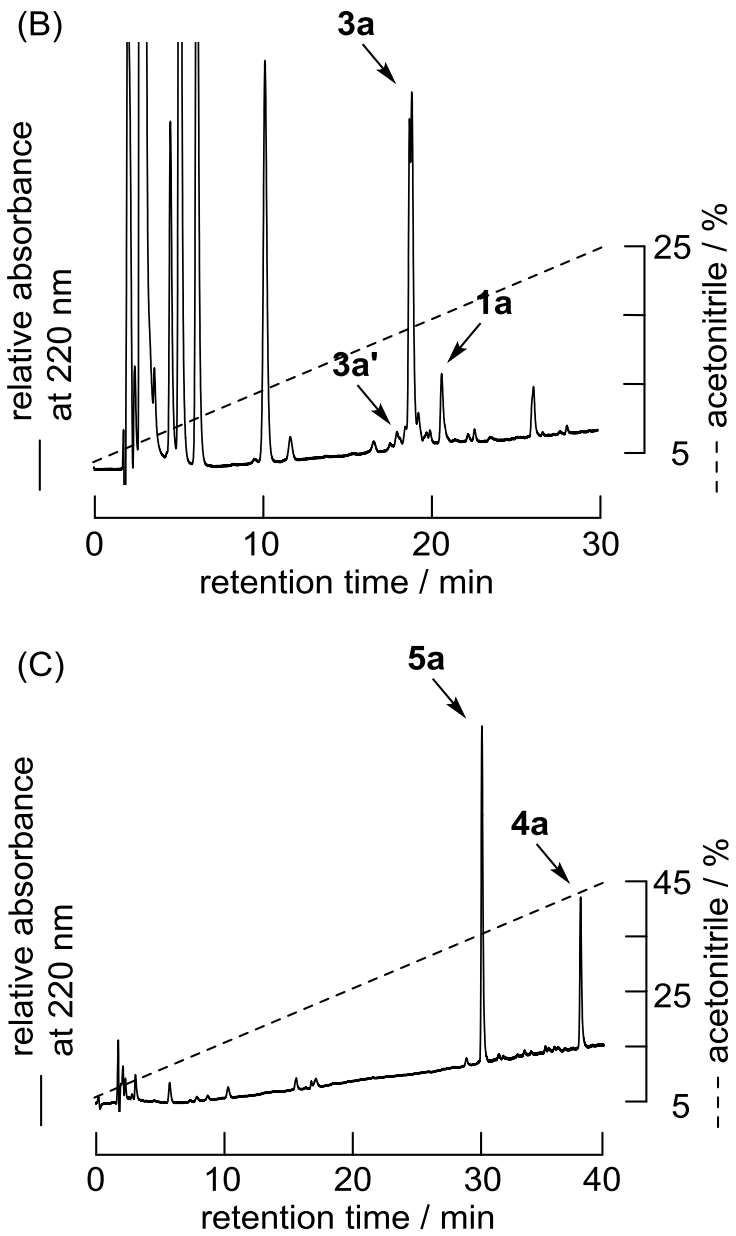

Figure 1. RP-HPLC of reaction mixtures of peptide 1a. (A) Reaction mixture of peptide $\mathbf{1 a}$ and thiirane $\mathbf{2}$ in sodium phosphate buffer (pH 8.0) containing glyoxylic acid at $37{ }^{\circ} \mathrm{C}$ after $24 \mathrm{~h}$; (B) Reaction mixture of peptide $6 \mathbf{a}$ at $37{ }^{\circ} \mathrm{C}$ after an additional $24 \mathrm{~h}$, after adding $O$-methylhydroxylamine; (C) Reaction mixture of peptide 3a and the CPE peptide 4a in sodium phosphate buffer ( $\mathrm{pH}$ 7.9) containing TFET at $37{ }^{\circ} \mathrm{C}$ after $8 \mathrm{~h}$. Column: YMC-Pack ProC18 $(4.6 \times 150 \mathrm{~mm})$, eluent: aq. acetonitrile containing $0.1 \%$ TFA, flow rate: $1.0 \mathrm{~mL} / \mathrm{min}$.
(A)

1

ARTKQTARKS TGGKAPRKQL ATKAARKSAP ATGGV ${ }^{35}$

(B)

\section{MQIFVKTLTG KTITLEVEPS DTIENVKAKI \\ QDKEGIPPDQ QRLIFAGKQL EDGRTLSDYN IQKESTLHLV LRLRGG ${ }^{76}$}

Figure 2. Amino acid sequence of (A) H3(1-35), in which Lys23, shown in red, was replaced by a Cys residue; (B) Ub, in which the amino acid residues, shown in red or blue, were introduced as a pseudoproline dipeptide or a Dmb dipeptide, respectively, during SPPS. $^{37}$

A far-UV circular dichroism (CD) spectrum of H3-Ub peptide 5b was measured and the spectrum was compared with those of recombinant $\mathrm{Ub}$ and synthetic $\mathrm{Ub}$, which was prepared by the hydrolysis of Ub-CPE $\mathbf{4 b}$ (Figure 4). The pattern of spectra of the recombinant and synthetic Ubs was identical, and was also very similar to previously reported ones. ${ }^{39}$ The spectrum of the H3-Ub peptide $\mathbf{5 b}$ was similar to spectra of Ubs without the H3 peptide in the $207-250 \mathrm{~nm}$ region, and was closely similar to the spectrum of a mixture of synthetic $\mathrm{Ub}$ and $\mathrm{H} 3$ peptide $\mathbf{1 b}$ (Figure S6), which indicated that $\mathrm{Ub}$ was correctly folded without any influence of the $\mathrm{H} 3$ peptide. The increase in the negative $\mathrm{CD}$ signal at a wavelength shorter than $207 \mathrm{~nm}$ further can be attributed to the presence of a random structure derived from $\mathrm{H} 3$ peptide.

In conclusion, 2-aminomethylthiirane $\mathbf{2}$ was efficiently introduced by a one pot procedure into the thiol group of Cys residues to produce a 1,2-amino-thiol moiety, which was used for native chemical ligation with peptide thioesters to produce isopeptide-mimetics. Although it was not possible to remove the thiol group under desulfurization conditions, the thiol group could be used for the labeling with fluorescent probes. In this report, ubiquitinated histone $\mathrm{H} 3$ peptide was successfully synthesized, and the Ub moiety was shown to be correctly folded without any influence by the random $\mathrm{H} 3$ peptide. The resulting product can be used for functional studies of ubiquitinated histone proteins. This procedure could also be used to prepare other isopeptides including small ubiquitin-related modifier (SUMO) proteins. 


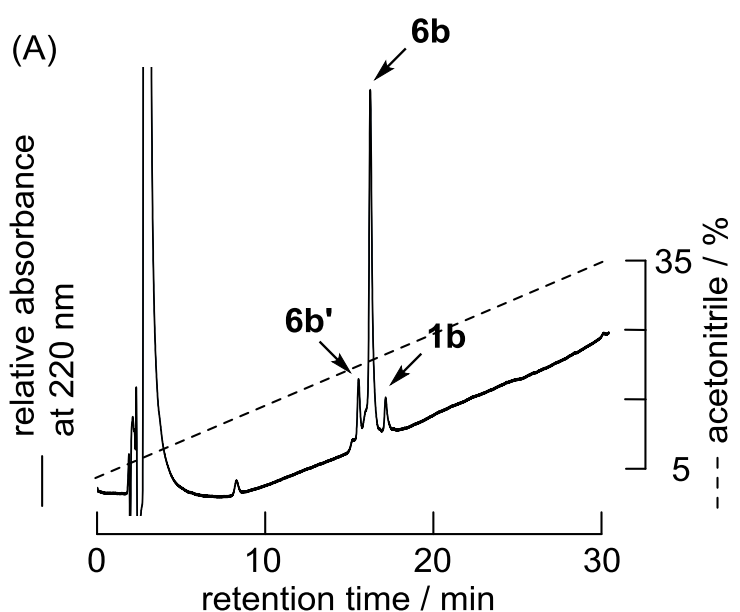

(B)
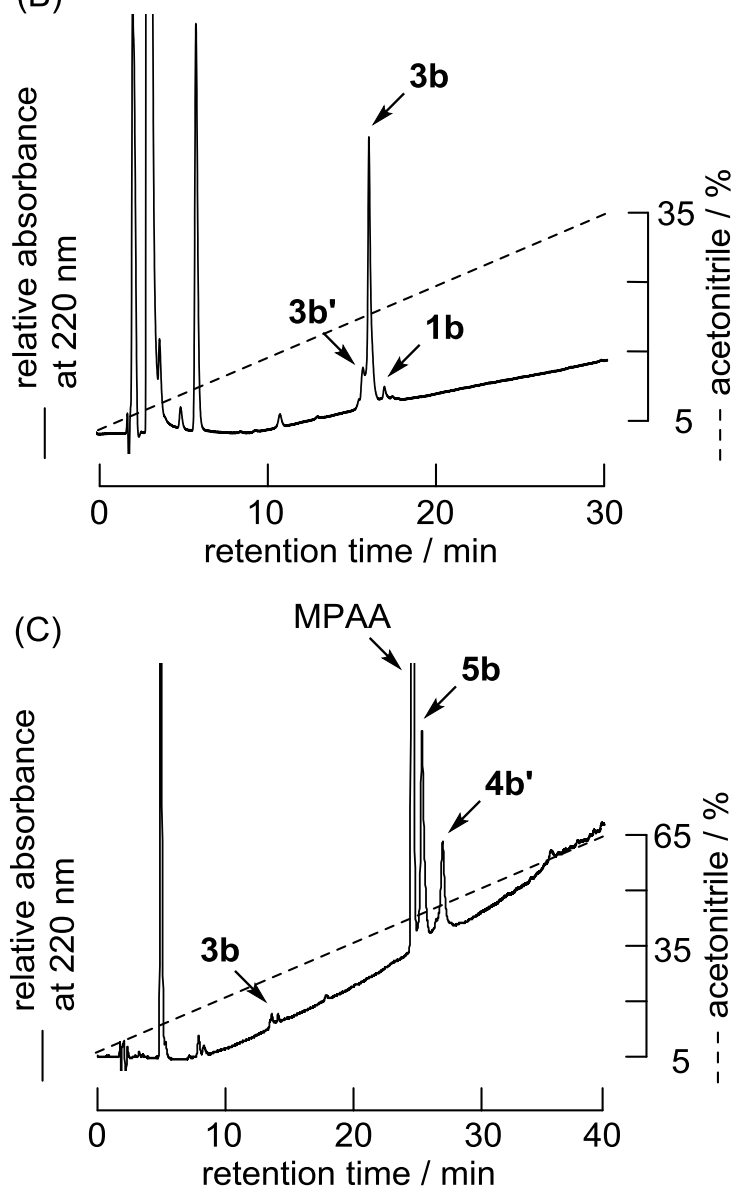

Figure 3. RP-HPLC of reaction mixtures of the histone $\mathrm{H} 3$ peptide. (A) Reaction mixture of the histone peptide $\mathbf{1 b}$ and thiirane $\mathbf{2}$ in sodium phosphate buffer ( $\mathrm{pH} 8.0$ ) containing glyoxylic acid at $37^{\circ} \mathrm{C}$ after $48 \mathrm{~h}$; (B) Reaction mixture of the peptide $6 \mathbf{b}$ at $37{ }^{\circ} \mathrm{C}$ after an additional $24 \mathrm{~h}$, after adding $O$-methylhydroxylamine; (C) Reaction mixture of peptide $\mathbf{3 b}$ and $\mathrm{Ub}-\mathrm{CPE} \mathbf{4} \mathbf{b}$ in sodium phosphate buffer (pH 8.0) containing MPAA at $37{ }^{\circ} \mathrm{C}$ after $24 \mathrm{~h}$. Column: YMCPack ProC18 $(4.6 \times 150 \mathrm{~mm})$, eluent: aq. acetonitrile containing $0.1 \%$ TFA, flow rate: $1.0 \mathrm{~mL} / \mathrm{min}$. $\mathbf{4 b}$ ': derivative of Ub-CPE $\mathbf{4 b}$.

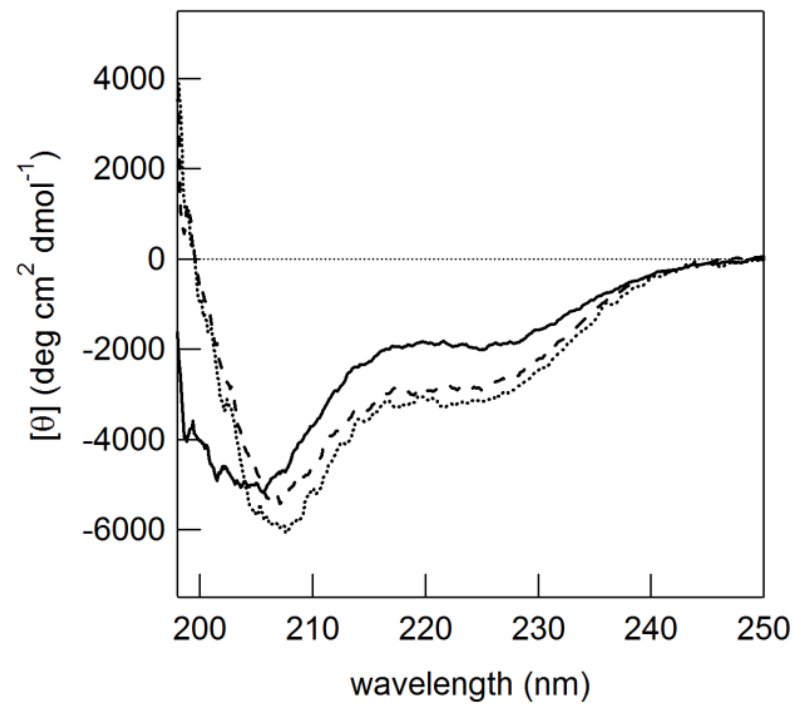

Figure 4. Far-UV CD spectra of recombinant Ub (dotted line), synthetic Ub (broken line), and the H3-Ub peptide $\mathbf{5 b}$ (solid line).

\section{Acknowledgments}

This research was supported, in part, by JSPS KAKENHI Grant Number 15K05565 (TK) and 15K14418 (IS), and IS was supported by a grant from CREST, Japan Science and Technology Agency (Grant Number 115201018). We wish to thank Dr. Daniel A. Erlanson at Carmot Therapeutics Inc., Prof. Hironobu Hojo, Prof. Shoji Tajima, and Prof. Yuji Goto at Institute for Protein Research for helpful discussions.

\section{References}

1. Krall. N.; da Cruz, F. P.; Boutureira, O.; Bernardes, G. J. L. Nat. Chem. 2016, 8, 103-113.

2. Walsh, C.T.; Garneau-Tsodikova, S.; Gatto, G. J. Angew. Chem Int. Ed. 2005, 44, 7342-7372.

3. Mu, M. M.; Muir, T. W. Chem. Rev. 2015, 115, 2296-2349.

4. Fischle, W.; Mootz, H. D.; Schwarzer, D. Curr. Opin. Chem. Biol. 2015, 28, 131-140.

5. Rothbart, S. B.; Strahl, B. D. Biochim. Biophys. Acta 2014, 1839, 627-643.

6. Jenuwein, T.; Allis, C. D. Science 2001, 293, 1074-1080.

7. Mishima, Y.; Watanabe, M.; Kawakami, T.; Jayasinghe, C. D.; Otani, J.; Kikugawa, Y.; Shirakawa, M.; Kimura, H.; Nishimura, O.; Aimoto, S.; Tajima, S.; Suetake, I. J. Mol. Biol. 2013, 425, 5470.

8. Mishima, Y.; Jayasinghe, C. D.; Lu, K.; Otani, J.; Shirakawa, M.; Kawakami, T.; Kimura, H.; Hojo, H.; Carlton, P.; Tajima, S.; Suetake, I. Nucl. Acids Res. 2015, 43, 10200-10212.

9. Kawakami, T.; Akai, Y.; Fujimoto, H.; Kita, C.; Aoki, Y Konishi, T.; Waseda, M.; Takemura, L.; Aimoto, S. Bull. Chem. Soc. Jpn. 2013, 86, 690-697.

10. Kawakami, T.; Yoshikawa, R.; Fujiyoshi, Y.; Mishima, Y.; Hojo, H.; Tajima, S.; Suetake, I. J. Biochem. 2015, 158, 403-411.

11. Abeywardana, T.; Pratt, M. R. ChemBioChem 2014, 15, 15471554.

12. Spasser, L.; Brik, A. Angew. Chem. Int. Ed. 2012, 51, 6840-6862.

13. Nishiyama, A.; Yamaguchi, L.; Sharif, J.; Johmura, Y.; Kawamura, T.; Nakanishi, K.; Shimamura, S.; Arita, K.; Kodama, T.; Ishikawa, F.; Koseki, H.; Nakanishi, M. Nature 2013, 502, 249-253

14. Qin, W.; Wolf, P.; Liu, N.; Link, S.; Smets, M.;, La Mastra, F.; Forné, I.; Pichler, G.; Hörl, D.; Fellinger, K.; Spada, F.; Bonapace, I. M.; Imhof, A.; Harz, H.; Leonhardt, H. Cell Res. 2015, 25, 911 929.

15. Bi, X.; Yang, R.; Feng, X.; Rhodes, D.; Liu, C.-F. Org. Biomol. Chem. 2016, 14, 835-839.

16. Siman, P.; Karthikeyan, S. V.; Nikolov, M.; Fischle, W.; Brik, A. Angew. Chem. Int. Ed. 2013, 52, 8059-8063.

17. McGinty, R. K.; Kim, J.; Chatterjee, C.; Roeder, R.; Muir, T. W. Nature 2008, 453, 812-816.

18. Yang, R.; Liu, C.-F. Top. Curr. Chem. 2015, 362, 89-106.

19. Zhou, L.; Holt, M. T.; Ohashi, N.; Zhao, A.; Müller, M. M. Wang, B.; Muir, T. W. Nat. Commun. 2016, 7, 10589

20. Sander, M. Chem. Rev. 1966, 66, 297-339. 
21. Takeuchi, H.; Nakajima, Y. J. Chem. Soc., Perkin Trans. 2 1998, 2441-2446.

22. Reddy, S.; Surendra, K.; Krishnaveni, N. S.; Narender, M. Helv. Chim. Acta 2007, 90, 337-339.

23. Aimoto, S. Biopolymers (Pept. Sci.) 1999, 51, 247-265.

24. Hojo, H.; Aimoto, S. Bull. Chem. Soc. Jpn. 1991, 64, 111-117.

25. Kawakami, T.; Kogure, S.; Aimoto, S. Bull. Chem. Soc. Jpn. 1996, 69, 3331-3338.

26. Kent, S. B. H. Chem. Soc. Rev. 2009, 38, 338-351.

27. Hackenberger, C. P. R.; Schwarzer, D. Angew. Chem. Int. Ed. 2008, 47, 10030-10074.

28. Dawson, P. E.; Muir, T. W.; Clark-Lewis, I.; Kent, S. B. H. Science 1994, 266, 776-779.

29. Kawakami, T. Top. Curr. Chem. 2015, 362, 107-136

30. Kawakami, T.; Aimoto, S. Chem. Lett. 2007, 36, 76-77.

31. Kawakami, T.; Aimoto, S. Tetrahedron Lett. 2007, 48, 1903-1905.

32. Kawakami, T.; Aimoto, S. Tetrahedron 2009, 65, 3871-3877.

33. Kawakami, T.; Kamauchi, A.; Harada, E.; Aimoto, S. Tetrahedron Lett. 2014, 55, 79-81.
34. Thompson, R. E.; Liu, X.; Alonso-García, N.; Pereira, P. J. B.; Jolliffe, K. A.; Payne, R. J. J. Am. Chem. Soc. 2014, 136, 81618164.

35. Wan, Q.; Danishefsky, S. J. Angew. Chem. Int. Ed. 2007, 46, 9248-9252.

36. Loibl, S. F.; Harpaz, Z.; Seitz, O. Angew. Chem. Int. Ed. 2015, 54, 15055-15059.

37. El Oualid, F.; Merkx, R.; Ekkebus, R.; Hameed, D. S.; Smit, J. J.; de Jong, A.; Hilkmann, H.; Sixma, T. K.; Ovaa, H. Angew. Chem. Int. Ed. 2010, 49, 10149-10153.

38. Johnson, E. C. B.; Kent, S. B. H. J. Am. Chem. Soc. 2006, 128, 6640-6646.

39. Kumar, K. S. A.; Spasser, L.; Erlich, L. A.; Bavikar, S. N.; Brik, A. Angew. Chem. Int. Ed. 2010, 49, 9126-9131. 


\section{Graphical Abstract}

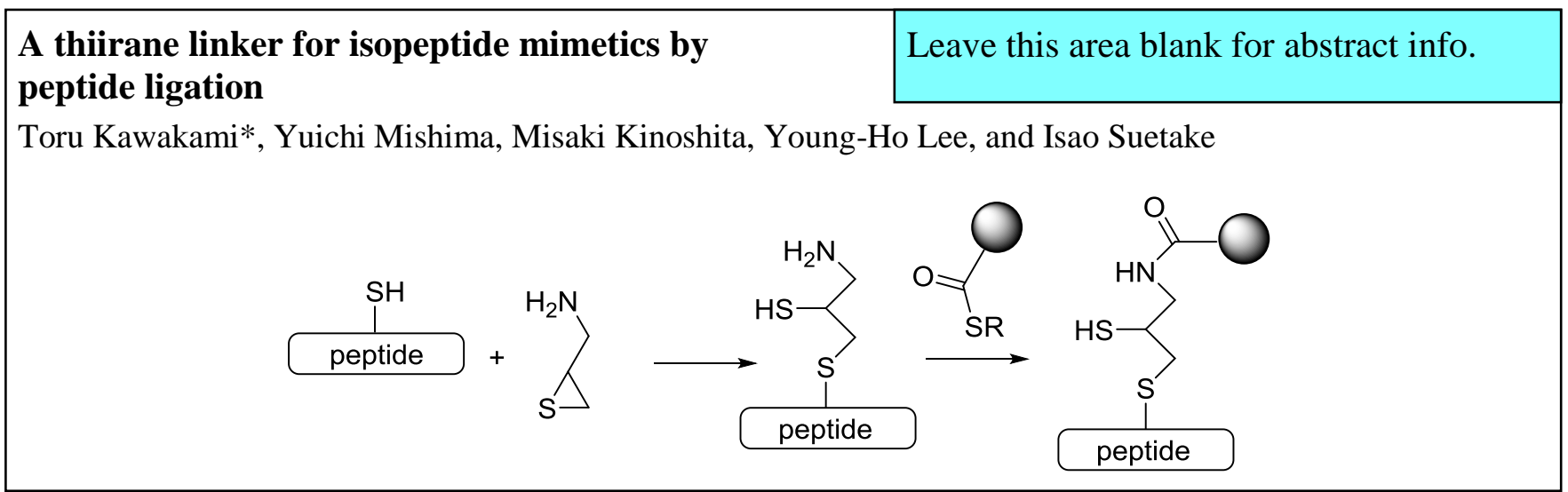

